UNIO - EU Law Jounal. Vol. 2, No. 2, June 2016, pp 82-96.

(2016 Centre of Studies in European Union Law

School of Law - University of Minho

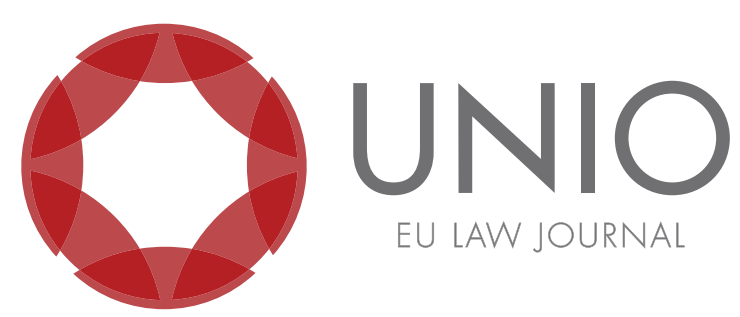

\title{
The interpretation complying with EU law manifested in the case law unifying judgment No. 15/2013 of the Portuguese Supreme Court of Justice
}

\author{
Carla Machado*
}

ABSTRACT: This article aims to address the interpretation that has been made by Portuguese courts in relation to the concept of "communication of the work to the public" enshrined in Article 3 (1) of Directive 2001/29/EC of the European Parliament and of the Council of 22 May 2001, duly transposed into the Portuguese legal order by Law No. 50/2006 of 24 August, which culminated in the drafting of the case law unifying judgment No. 15/2013. By verifying its content and analysing the case law of the Court of Justice of the European Union (hereinafter CJEU), concerning the interpretation of that concept, we conclude that the said case law unifying judgment does not comply with EU law. Therefore, we will list, on the one hand, the inherent consequences regarding the upkeep of the interpretation that has been held by the Portuguese judicial authorities and, on the other, we will suggest solutions for the resolution of similar cases by appealing to the principle of conforming interpretation.

KEYWORDS: Directive 2001/29/EC of the European Parliament and of the Council of 22 May 2001 - case law unifying judgement of the Portuguese Supreme Court of Justice No. 15/2013 - communication of the work to the public-principle of conforming interpretation of national law with EU law.

\footnotetext{
*Magistrate and Master candidate in European Union Law, University of Minho, Portugal.
} 


\section{The case law unifying judgment No. $15 / 2013^{1}$}

The discussion of whether the distribution of sound made by speakers that extend it - but that are not a part of the television or radio device - going beyond the mere reception, resulting in a new broadcast of the programme, was the subject of a wide judicial disagreement at the national level.

For some, it was considered to be a crime of misuse, punishable by virtue of Article 195 (1) and Article 197 (1) of the Copyright and Related Rights Code (hereinafter CRRC). The fact that the person in charge of the establishment amplified the sound of the broadcast, arguably, meant that this broadcast was being disseminated to a diverse audience through a television and a separate speakers set, without the consent of the authors of the songs or their representatives.

It was, therefore, understood that the agent, when connecting the speakers to the television, did not just make a mere reception of a television programme in public; the agent was also broadcasting signals, sounds and images. Thus, it was held that there was a need for the authorization from the authors of works that were broadcasted. $^{2}$

For others, the aforementioned conduct did not constitute the practice of the crime of misuse, distinguishing between receiving transmission and reception amplification and considering that only the first lacked authorization, for it took on the characteristics of a new communication-broadcasting of the work to the public. ${ }^{3}$

The case law unifying judgment No. 15/2013 (hereinafter, CLUJ) of the Portuguese Supreme Court of Justice (henceforth, SCJ) terminated that dispute by establishing case law concluding that "the application of sound amplification devices to a television, broadcasting by television channel, in a commercial establishment, does not constitute a new use of the broadcasted work and therefore does not require authoriation of its author, thus this practice does not perpetrate the crime of misuse, foreseen and punishable by Articles 149, 195 and 197 of the Copyright and Related Rights Code."

The SCJ reinforced its position by citing relevant doctrine and jurisprudence such as, the Opinion No. 4/92 of the Advisory Council of the Prosecutor-General's Office. ${ }^{4}$ It also analysed the applicable legal provisions. ${ }^{5}$

The Court then, proceeded to distinguish between reception and communication: "the reception is to capture through the appropriate equipment the signals and sounds and images broadcasted by the transmitter...It is the terminus of the transmission process and it alone justifies it: it is transmitted by broadcast to the receiver. This use of works by the receiver naturally confers the authors the right to use (and the consequent right to remuneration for such use) in accordance with

\footnotetext{
${ }^{1}$ Published in Diário da República, 1st series, No. 243, of 16 December 2013, 6821-6828.

${ }^{2}$ See the Seizure Order the Court of Appeal of Oporto of 03.08.1995 (case No. 9311103), the Court of Appeal of Lisbon of 17.02.2002 (case No. 85665) and of 15.05.2007 (case No. 72/2007-5) and the Court of Appeal of Guimarães of 02.07.2007 (case No. 974/07.2), available at www.dgsi.pt.

${ }^{3}$ Cf., In this sense, among others, the judgments of the Court of Appeal of Guimarães of 04.04.2011 (case No. 1130 07.3TABRG.G1), the Court of Appeal of Lisbon of 22.03.2011 (case No. 147/04.4SXLSB.L1, 5th) and the Court of Appeal of Oporto of 19.09.201 2 ratio (case/2 No. 131/11.GEGDM.P1), available at www.dgsi.pt.

${ }^{4}$ Voted on 05.28.1992 and approved on 07.27.1992.

${ }^{5}$ Among others, Article 42 (1) and (2) of the Constitution of the Portuguese Republic, and Articles 67, 68, 149, 155, 195 and 197 of the CRRC.
} 
paragraph 1 of Article 149. However, once authorized, the reception is free, that is, the receiver may organize it at will, providing that it remains within the reception's scope. It is therefore necessary to distinguish between the mere reception (signal reception) and the reuse of the work provided for in Article 149 (2). This provision has to refer to situations where the transmission adds, modifies, or innovates, thus constituting a new use of the work. This new use necessarily requires any modification by technical means in the form of reception in order to draw on it to produce a spectacular visual or sound effect, to create an enactment that the mere reception of the broadcasted programme does not create." ${ }^{6}$

It will be the case referred to in the judgment and defended by Oliveira Ascensão, ${ }^{7}$ that will determine whether or not entry payment occurs: "all aimed at attracting a wider audience than that which would normally occur in the establishment."

Referring to C-162/10 of the CJEU' the SCJ says that "the same solution will be accepted in the case of a multiplied reception, as in hotels, where the reception is distributed in the rooms and common rooms, which translates, in addition to the exponential amplification of the broadcasted signal, in an extra service provided by the botel to the guests, likely to attract clientele, and therefore profits, so it can be considered a work reuse, for which remuneration is due."10

Despite being fully aware of the contrary position advocated by the CJEU ${ }^{11}$ one may also read in the aforementioned CLUJ that "such will no longer will be the case of the mere reception in cafes or bars open to most people, with no payment of entry requirement, establishments which traditionally represent conviviality or meeting places, especially in small communities, but not limited to them, in which the uptake of television programmes can operate occasionally as a special decoy, but usually only serves the established clientele for which it is not an attraction."

Consequently, the mere reception, even if changed by accessory equipment including speakers and that may not originally be part of the device - provided it is limited to the function enhancement/improvement, Article 149 (2) of the CRRC, does not apply, otherwise the use of the same work would imply a double recovery of rights. ${ }^{12}$

\section{The directive on copyright and related rights}

Directive 2001/29/EC of the European Parliament and of the Council of 22 May 2001 on the harmonization of certain aspects of copyright and related rights in the information society, was transposed into Portuguese law by Law No. 50/2004, of 24 August, introducing therefore amendments to the Decree-Law No. 63/85, of 14 May. ${ }^{13}$

\footnotetext{
${ }^{6}$ Vide, A.U.J n. ${ }^{\circ}$ 15/2013, in Diário da República, 1st series, No. 243, of 16 December 2013, 6827.

${ }^{7}$ In Direito Civil - Direito de Autor e Direitos Conexos, 2008, 311 and 312.

${ }^{8}$ Vide, A.U.J n. ${ }^{\circ}$ 15/2013, in Diário da República, 1st series, No. 243, of 16 December 2013, 6827.

${ }^{9}$ Judgment of the CJEU of 15.03.2010.

${ }^{10}$ Idem ibidem.

${ }^{11}$ Specifically, in footnote 7 it is expressly referred Case C-403/08 and 429/08, both of 04.10.2011.

${ }^{12}$ In addition, and for the purposes of intellectual property as a fundamental right, see Luís Couto Gonçalves, in Carta dos Direitos Fundamentais da União Europeia Comentada, Alessandra Silveira and Mariana Canotilho (eds.), Almedina, 2013, p. $221 \mathrm{ff}$.

${ }^{13}$ Under international law it is urgent to recall that the European Community has approved, through Decision 94/800/EC of 22 December 1994, the Agreement on Trade-Related Aspects of Intellectual Property Rights, which constitutes Annex $1 \mathrm{C}$ to the Agreement establishing the World
} 
It can be read in its recitals that this legal instrument is based on principles and rules already established in the directives in force in the field of intellectual property, implementing some of the obligations under international law ${ }^{14}$ and developing and integrating them within the perspective of the information society.

One of the underlying purposes of the adoption of the directive under review was the further harmonization of copyright laws applicable to communication of works to the public. These should, therefore, be understood in a broad sense, as covering any transmission or retransmission of a work to the public by wire or wireless means, including broadcasting.

Notwithstanding, it should be recalled that this directive states, on the one hand, that such harmonization is based on a high level of protection - as copyright and related rights are believed to be crucial to intellectual creation - and, on the other, the attribution to authors, interpreters and/or performers of an appropriate reward for the use of their work, so that they may continue their creative and artistic work.

Furthermore, a fair balance of rights and interests between the different categories of right holders must be safeguarded, as well as between the different categories of right holders and users of protected material.

Otherwise, the exclusive right of reproduction should be subject to an exception to allow certain acts of temporary reproduction, which are transient or incidental reproductions, forming an integral and essential part of a technological process for the sole purpose of enabling either efficient transmission in a network between third parties by an intermediary, or a lawful use of a work or other protected subject matter. The acts of reproduction concerned should have no inherent economic value. To the extent that these conditions are met, this exception should include acts which enable browsing and acts of caching, including those permitting the efficient operation of transmission systems, provided that the intermediary does not modify the content of the transmission and does not interfere with the lawful use of technology, widely recognized and used by the industry, to obtain data on the use of the information. Finally, consideration is given to the fact that a use should be considered legitimate if it is authorized by the right holder and is not restricted by law.

Article 3 (1) of that directive, entitled "Right of communication to the public of works," including the right of making available to the public other subject-matter, states that "Member States shall provide the authors with the exclusive right to authorize or probibit any communication to the public of their works, by wire or wireless means, including the making available to the public in order to make them accessible to anyone from the local and at the time individually chosen by them."

With direct relevance to the present case, and despite being an earlier version prior to the transposition of the directive, consideration should be given to the provisions of Article 149 (2) of the CRRC, which prescribes that the communication of works in any public place by any means serving to broadcast signals, sounds or images is subject to authorization. In turn, Article 155 of the same law provides that; "remuneration is due also to the author for public communication of the broadcasted work by loudspeaker or any other analogous

Trade Organization (WTO) signed in Marrakesh on 15 April 1994 (commonly referred to as the TRIPS Agreement). In turn, the World Intellectual Property Organization (WIPO) adopted in Geneva on 20 December 1996, the WIPO Performances and Phonograms Treaty and the WIPO Copyright Treaty, which were approved by the European Community through Decision 2000/278/ EC of 16 March 2000.

${ }^{14}$ In particular, Directive 92/100/EEC of the Council of 19 November 1999 on the rental right and lending agreement and certain rights related to copyright in the field of intellectual property. 
instrument transmitting signals, sounds or images."

Finally, Articles 195 and 197 punish, as a crime of misuse, whoever, without permission of the author, or artist, the producer of phonogram and or the broadcasting organization, uses a work or performance by any of the forms provided for in the CRRC.

\section{The case law of the CJEU}

At this point, it is necessary to pay attention to the CJEU case law. In the judgment of 4 October 2011, the CJEU ruled stating that "communication to the public' within the meaning of Article 3 (1) of the Copyright Directive must be interpreted as covering transmission of the broadcast works, via a television screen and speakers, to the customers present in a public house."15 16

In casu, the facts were related with the grant of television broadcasting rights for live coverage of the Premier League, administered by the FAPL, which carries out such concession given the territorial basis and for three years.

In order to protect the territorial exclusivity, each of the contracting parties undertakes to prevent the public from receiving their broadcasts outside the area for which they hold the license. This implies, on one hand, that emissions are securely encrypted in order to prevent their capture in an unencrypted form, and on the other, broadcasting bodies are prohibited from supplying decoding devices that allow their broadcasts to be decrypted with the view of being used outside the territory for which they hold the license.

At the time, the holder of such rights in the UK was BSkyB Ltd. Therefore, those wishing to screen these games in that country had to take out a commercial subscription from the aforesaid company.

However, some establishments had begun to use foreign decoding devices to access Premier League matches, which were manufactured and marketed with the authorization of the service provider for their dissemination in Greece, but were used in an unauthorized manner (outside the territorial space for which they had been marketed and provided). For this reason, the FAPL considered that these activities were detrimental to their interests for they affected the exclusivity of the rights granted under license to a particular territory, and thus its value.

To achieve the abovementioned conclusion, the CJEU recalled that since Directive 2001/29/EC does not define the concept of communication to the public, its meaning must be determined "in light of the objectives pursued by the Copyright Directive [that we list above] and of the context in which the provision being interpreted is set (SGAE, paragraph 34 and the case-law cited)."

More specifically, it held that Article 3 of the copyright directive must be interpreted considering i) the establishment of a higher level of protection of copyright coupled with the right to adequate compensation for use of the work, leading to a broad concept of communication to the public; ii) the copyright directive is based on principles and rules already established in the directives in force in the field of intellectual property, such as Directive $92 / 100,{ }^{17}{ }^{18}$ so taking into account the principle of the Union's legal unit and its coherence, the concepts used in all these

\footnotetext{
${ }^{15}$ Joined Cases C-403/08 and C-429/08.

${ }^{16}$ Cf. recital No. 207.

${ }^{17}$ Under Article 8 (3) of the Directive on Related Rights the concept of communication to the public includes the operation of making the sounds or representations of sounds fixed in a phonogram audible to the public, encompassing broadcasting or any communication to the public.

${ }^{18}$ Cf. Judgment of the CJEU of 16 July 2009 (Infopaq International, C-5/08).
} 
Directives must have the same meaning unless the EU legislature has, in a specific legislative context, expressed a different intention, ${ }^{19}$ iii) international law, taking in particular account the Berne Convention ${ }^{20}$ and the Copyright Treaty. ${ }^{21}$

The CJEU, without neglecting the fact that the customer is present within the area covered by the broadcast, took for granted that the access to the broadcast transmission of protected works via a television screen and speakers, was only possible due to the intervention and deliberate permission of the pub owner.

Under this assumption - of effective communication in the deliberate transmission of broadcasted works - the CJEU put forward three criteria, to be appraised on a case by case basis by the law enforcer in order to determine what constitutes "communication to the public:"

i) Assess whether the broadcast work is transmitted to a new public, i.e., "a public that was not considered by the authors of the protected works when they authorized its use by communication to the original public." 22 Here it is urgent to point out that "When those authors authorise a broadcast of their works, they consider, in principle, only the owners of television sets who, either personally or within their own private or family circles, receive the signal and follow the broadcasts. Where a broadcast work is transmitted, in a place accessible to the public, for an additional public which is permitted by the owner of the television set to hear or see the work, an intentional intervention of that kind must be regarded as an act by which the work in question is communicated to a new public";

ii) Ascertain whether the broadcast work is being transmitted to "a public not present at the place where the communication originates. ${ }^{23}$ It should, therefore, be stated that the concept of communication to the public does not cover "direct representation or performances," that is, the interpretation of works before an audience that is in physical and direct contact with the author or performer of those works; ${ }^{24}$

iii) Conclude on the profit-making nature of the communication, which is reflected both in the attendance of the establishment, and in its economic

\footnotetext{
${ }^{19}$ As the European Union legislator has not expressed a different will concerning the interpretation of "communication to the public" in the copyright directive, particularly in Article 3, it shall be construed, as stated by the CJEU in the judgment under analysis, that the mentioned concept is aimed at "any transmission of the protected works, irrespective of the technical means or process used." Moreover, following this interpretation in Judgement $S G A E$ the CJEU ruled that an owner of a hotel establishment carries out an act of communication by allowing its clients to access the broadcast works via television sets, distributing in hotel rooms the received signal containing the protected works, with full knowledge of the facts. This is because, it stresses, "such intervention is not just a technical means to ensure or improve reception of the original broadcast in the catchment area, but an act without which those customers are unable to enjoy the broadcast works, although physically within that area."

${ }^{20}$ Article 11 bis, (1), iii) of the Berne Convention states that the concept of communication to the public encompasses communication through a speaker or any other instrument transmitting signals, sounds or images, covering a means of communication like displaying the works on a screen.

${ }^{21}$ Cf. recitals 185 to 189 .

22 See also the aforementioned Judgement SGAE and order Organismos Slllogikis Diacheirisis Dimiourgon Theatrikon kai Optikoakoustikon Ergon.

${ }^{23}$ For the purposes of the twenty-third recital of the directive on copyright.

${ }^{24}$ Cf. Article 11, first paragraph of the Berne Convention and the Guide of the Convention that, despite constituting only an interpretative document and as such having no binding force, contributes to the interpretation of the Convention, as highlighted in Judgement SGAE.
} 
results. ${ }^{25}$

Returning to the main proceedings, the CJEU concludes that the listed requirements were met. In fact, it found that the public in the pub was broader because it was not taken into account by the authors upon their approval of the broadcasting of their works. Furthermore, the physical and direct contact element would inevitably be excluded in the case of transmission in a pub via a television screen and speakers to an audience that is not present at the place where the communication originates. And finally, one could not forget that the owner proceeded to transmit broadcasted works for profit, and that such communication was likely to attract customers interested in the transmitted works.

However, in the CJEU Judgment of 15 March 2012, Case C-135/10, it was understood that

“The concept of 'communication to the public' which appears in Council Directive 92/100/EEC of 19 November 1992 on rental right and lending right and on certain rights related to copyright in the field of intellectual property and Directive 2001/29/EC of the European Parliament and of the Council of 22 May 2001 on the harmonisation of certain aspects of copyright and related rights in the information society must be interpreted in the light of the equivalent concepts contained in the convention, the agreement and the treaty mentioned above and in such a way that it is compatible with those agreements, taking account of the context in which those concepts are found and the purpose of the relevant provisions of the agreements as regards intellectual property (...)The concept of 'communication to the public' for the purposes of Article 8(2) of Directive $92 / 100$ must be interpreted as meaning that it does not cover the broadcasting, free of charge, of phonograms within private dental practices engaged in professional economic activity, such as the one at issue in the main proceedings, for the benefit of patients of those practices and enjoyed by them without any active choice on their part. Therefore, such an act of transmission does not entitle the phonogram producers to the payment of remuneration." 26

In the statement of the facts, it reads that within Italy and outside the Italian territory, SCF (Società Consortile Fonografici) develops the collecting activity as an agent for the management, collection and distribution of the rights of its associated phonogram producers.

In pursuit of such activity, it started negotiations with the Italian Dentists Association with a view to concluding a collective agreement on the establishment of an equitable remuneration amount for any communication to the public, including the one carried out in the offices of private professional practices, which, however, failed.

Regarding the concept of user, the CJEU recalled that it had already decided that the operator of a hotel and a café-restaurant carries out an act of communication to the public within the meaning of Article 3 (1) of Directive 2001/29/EC when it intervenes, in full knowledge of the consequences of its behaviours, to give its customers access

${ }^{25}$ Cf. recitals 198 to 205.

${ }^{26} \mathrm{Cf}$. operative part of the judgment. 
to a broadcast containing the protected work, since without this intervention, and even though the customers are physically within the broadcast's catchment area, they could not, in principle, enjoy the broadcasted work.

On the concept of the public, it claims that it "refers to an indeterminate number of potential listeners, and, in addition, implies a fairly large number of persons. ${ }^{227} 28$

Returning to the present case, the CJEU did not hesitate in stating that customers only enjoyed the phonograms by reason of the deliberate intervention of the dentist.

It also submitted that the dentist's customers form a determinate circle of potential recipients whose composition is stabilized, since generally people do not have access to treatment by this particular dentist.

Moreover, it was understood that the number of people present in that practice at the same time is negligible: "(...) although there are a number of patients in succession, the fact remains that, as those patients attend one at a time, they do not generally hear the same phonograms, or the broadcast phonograms, in particular. ${ }^{29}$

Finally, there is not a cause-effect relationship between the broadcasting of works and the increase in clientele, for unlikely to affect the dentist's income.

With greater importance to the solution that we intend to put forward is, undoubtedly, the judgment ${ }^{30}$ of the Court of Justice of 14 July 2015, due to a reference for a preliminary ruling by the Court of Appeal of Coimbra, where it was questioned whether "the concept of communication of work to the public provided for in Article 3 (1) of Directive 2001/29/EC must be interpreted as covering the transmission of broadcasted works, in commercial establishments such as bars, cafes, restaurants or others with similar characteristics, through television receptor sets and the broadcasting of which is magnified by speakers and/ or amplifiers, setting by that extent, a new use of works protected by copyright?'31 32

If it is true that from the case law of the CJEU does not results that the use of technical means to ensure or improve the original broadcast in the catchment area enshrines the concept of communication laid down in Article 3 (1) of Directive 2001/29/EC. one cannot overlook the fact that "the use of speakers and/or amplifiers to increase the broadcasting of sound (...) is not just a technical means to ensure or improve the original broadcast in the catchment area, since such intervention constitutes an act without which customers of the

\footnotetext{
${ }^{27}$ Cf. Judgment Mediakabel of 2 June 2005, Case C-89/04, and Lagardère Active Broadcast of 14 July 2005, Case C-192/04.

${ }^{28}$ The "indeterminate nature of public" is equivalent, according to the definition of public broadcast of the WIPO Glossary, to making "a work [...] perceptible in any appropriate manner to persons in general, that is, not restricted to specific individuals belonging to a private group." Meanwhile, a "a fairly large number of people" is aimed at a certain de minimis threshold, therefore, excluding from this concept a small or even negligible group of people. To determine this number account must be taken to the number of people who have access to the same work and how many of them have access to it in succession.

${ }^{29}$ Cf. Recital 96.

${ }^{30}$ Pursuant to Article 104 (3) of the Rules of Procedure of the CJEU, if the response is clearly deductible from its case law, the CJEU may decide by reasoned order.

${ }^{31}$ Reference for a preliminary ruling from the Court of Appeal of Coimbra (Portugal) on 30 March 2015, Case C-151/15 (2015/C 205/229) published in the Official Journal of the European Union of 22.06.2015 in which the appellant is the Portuguese Society of Authors CRL and the defendant is the Prosecutor's Office.

${ }^{32}$ Although we tend to think that by virtue of the doctrine of acte clair (which is reinforced by the fact that the matter has been decided by a mere order) national courts were able to resolve the matter in accordance with Union law per se, we welcome the position taken by the Court of Appeal of Coimbra to proceed with the reference for preliminary ruling, thus contradicting the majority view of the case law that has followed, without further ado, the CLUJ No. 15/2013.
} 
establishment in question cannot in principle enjoy the works broadcast, although they are within the said area (see in this sense, SGAE, C-306/05, EU:C:2006:764, recital ${ }^{\circ} 42$ )." ${ }^{\prime 33}$

As to the remainder, it should always be noted that "like the customers of a hotel, customers of a cafe-restaurant come and go quickly and are usually a rather large number of people and should be considered as public, given the main objective of Directive 2001/29, noted in recital 12 of this order (see in this sense, SGAE, C-306/05, EU:C:2006:764, recital 38)." And this public is new, i.e., an additional public which was not taken into account by the authors upon their authorisation for the broadcasting of their works.

There are also no questions with respect to the non-existence of physical and direct contact, inasmuch as the public present at the place where the transmission is made is not present at the location from which the communication originates.

Finally, and with regard to the "profit-making nature of the communication to the public" the Court has stated that "this transmission is likely to attract customers interested by the works thus transmitted and wherein said transmission is consequently impacting the attendance of the establishment and, in fine, in its economic results, such transmission is a communication to the public with profit-making purposes." 34

Thus, the Court ends by ruling on the meaning of

"the concept of 'communication to the public' pursuant to Article 3 (1) of Directive 2001/29/EC of the European Parliament and of the Council of 22 May 2001 on the harmonization of certain aspects of copyright and related rights in the information society, must be interpreted as meaning that it covers the transmission, via a radio device connected to speakers and/or amplifiers, by the people who operate a cafe-restaurant, of musical works and musical literary works broadcast by a radio station to customers who are present in such establishment. ${ }^{\prime 35}$

\section{The noncompliance of the CLUJ. Consequences and possible solutions}

Comparing the arguments put forward by the CJEU, set out in the various listed decisions, we maintain that, contrary to what is stated in the CLUJ No. 15/2013, if the reception in a public place involves the use of technical means - as are the speakers, loudspeakers or similar instruments - there is a retransmission and not just a reception expansion, which, provided that some criteria are met, justifies a new remuneration as provided for in Articles 155 and 149 (2) of the CRRC, notwithstanding any criminal liability provided by the combined provisions of Articles 195 and 197 of the same law.

As such, and while the SCJ does not change the established case law, national courts must decide on the inapplicability of CLUJ No. 15/2013. With the integration of the Portuguese State in the European [Union] legal system ${ }^{36}$ we witnessed a phenomenon

\footnotetext{
${ }^{33}$ Cf. recital n. ${ }^{\circ} 17$.

${ }^{34}$ Cf. recital n. ${ }^{\circ} 27$.

${ }^{35}$ Order of the Court of Justice (Third Chamber) 2015/C 320/20, published in the Official Journal of the European Union of 28/09/2015.

${ }^{36}$ In Judgement Faminio Costa v. E.N.E.L, of 15 July 1964, Case 6-64, the Court defined case law setting that the founding Treaties have created a legal framework, which should be respected by all national authorities "By creating a Community of unlimited duration, having its own institutions, its own personality, its own legal capacity and capacity of representation on the international plane and, more particularly, real powers stemming from a limitation of sovereignty or a transfer of powers from the States to the Community, the Member States have limited their sovereign rights, albeit within limited fields, and have thus created a body of
} 
hitherto completely unknown: the coexistence of two separate legal orders and, therefore, a relationship between organically European courts (from which we highlight the Court of Justice for its unquestionable relevance as far as the preliminary ruling is concerned) and functionally European courts (national courts of the Member States).

In the internal legal system, the case law unifying judgments are an indirect source of law, given that, pursuant to Article 445 (3) of the Criminal Procedure Code, they are not mandatory case law for the courts, thus being lawful for the judge to substantiate differences concerning the established case law.

On the contrary, the decisions of the CJEU constitute a direct source of law by allowing the uniformity and harmonization in the implementation of Union law in the territory of the Member States.

Thus, in addition to the express provision of some of the underlying principles of EU law provided for in Article 2 TFEU, ${ }^{37}$ and some of the general principles of $\mathrm{EU} \mathrm{law}^{38}$ it is necessary to pay attention to the role of the case law on principles of the $\mathrm{CJEU}^{39}$ that still enjoy binding precedent, and it is particularly relevant in fixing principles and their subsequent densification.

It is clear from Article 4 TEU (the principle of European loyalty or sincere cooperation $)^{40}$ that the Union and the Member States respect and mutually assist each other in carrying out tasks emanating from the Treaties, being the Member States entrusted to adopt measures enabling the implementation of obligations under the Treaties or resulting from the institutions of the Union and, also, facilitate the achievement of the Union's task(s), refraining from any measure which could jeopardize the attainment of those objectives. ${ }^{41}$

From the principle of European loyalty, the CJEU decomposed a number of other principles to ensure the objectives of this Union of law, based on criteria of reciprocity and equality of its citizens, from where we highlight the principle of primacy, the principle of conforming interpretation and the principle of the Member State's judicial liability for breaching European obligations.

The principle of primacy highlights the prevalence of the Union law over noncompliant national law, which derives from the preferred application of some standards, equally and prima facie valid, although emanating from a different source.

It is internally embodied in Article 7 (6) and Article 8 (4) of the Portuguese

law which binds both their nationals and themselves." More recently, in Judgement Segui, of 27 February 2007, Case C-355/04P, the Court of Justice reaffirmed the principle of Union of law, extending its preliminary rulings to 3 rd pillar matters (which, to date, were already only limited to Police and Judicial Cooperation in Criminal Matters) to ensure its own effective judicial protection.

${ }^{37}$ In the words of Alessandra Silveira, these are the principles "that correspond to the foundations of European legal culture - rule of law, democracy, fundamental rights," in Princípios de Direito da União Europeia, Doutrina e Jurisprudência, 2nd updated and expanded edition, Quid Iuris, p.11.

${ }^{38}$ Still quoting the words of Alessandra Silveira, in op. cit., p. 11, such will be the "principles that are directly or indirectly enrolled in the constituent treaties, constituting a normative reference presupposed by the very idea of Union of law, and make up material acts of European public authorities."

${ }^{39}$ On this subject see Jan Komárek, "Federal elements in the Community judicial system: building coherence in the Community legal order", in Common Market Law Review, No. 42, 2005.

${ }^{40}$ On the subject of the principle of loyalty by the CJEU see John Temple Lang, "Community constitutional law: Article 5 EEC Treaty", in Common Market Law Review, Vol. 27, No. 4, 1990.

${ }^{41}$ With relevance to the case under analysis, it is urgent to remember that in Judgement Factortame, of 19 June 1990, Case C-213/89, the CJEU even said that, under the principle of European loyalty, the courts must ensure the effective judicial protection of rights arising from the legal order of the European Union from which therefore arises the obligation of the court to disregard a rule of national law in order to ensure the application of Union law. 
Constitution, and addresses both the public administration and the national court, but mainly the latter, which is responsible for supervising and ensuring the application of Union law and its effective judicial protection.

Nonetheless, the national court should only draw on the principle of primacy, pushing a rule of national law incompatible with EU law, if the interpretation of domestic law in light of it is not enough to safeguard a right which the European legal order confers to the individual. Therefore, the principle of conforming interpretation with Union law, which stems from the interpretation given by the CJEU to the combined provisions of Article 4 (3) TEU and Article 288 (3) TFEU, requires the interpreter or administrator of national law to ascribe to national provisions a meaning compliant or compatible with the provisions of EU law.

In Von Colson ${ }^{42}$ the CJEU held that the obligation to interpret a national standard transposing a Directive in accordance with its text and purpose, requires the national court to give priority to the method - amongst the interpretation methods permitted by national law - enabling it to assign to the national provision at issue an interpretation consistent with the Directive. The interpretation thus made will only be limited by the general principles of legal certainty and non-retroactivity.

Similarly, in Kolpinghuis ${ }^{43}$ the CJEU held that the conforming interpretation could not give rise to criminal liability that had not been established by a national law adopted to implement the Directive. On the other hand, and despite being under the provisions, at the date, of the third pillar, it was decided in Maria Pupino ${ }^{44}$ that the principle of conforming interpretation could not serve to drive or increase the criminal liability of those who violate a framework decision nor serve as a basis for a contra legem interpretation of national law.

But the CJEU goes even on the scope of this principle. In Marleasing $g^{45}$ the Court held that this obligation exists not only with regard to national provisions designed to comply with the directive, but for the whole body of rules of national law. ${ }^{46}$

Of note, also, is the case law set in Marks \& Spencer ${ }^{47}$ towards granting individuals the right to invoke the provisions of a Directive against the Member State in all cases where its full implementation is not, in fact, secured, that is, not only in cases of failure to transpose or when it has been incorrectly transposed, but also in the event that the national measures are not applied in order to achieve the result sought by it.

It is, therefore, difficult to understand the position advocated by the SCJ upon the making of the CLUJ No. 15/2013. Without going into the details of the arguments adduced as to whether the use of speakers constitutes an act of receiving/transmitting a broadcast or enlarged reception, we cannot fail to note that the SCJ, when taking a position on this matter, does so with full knowledge of the case law of the CJEU and in defiance of it, quoting even in a footnote the CJEU's jurisprudence in the opposite direction to the position advocated.

Imposing itself to the judge interpreting a provision of national law in the light of EU law - and if such an interpretation is not sufficient to safeguard a right that

\footnotetext{
${ }^{42}$ Judgment Von Colson, of 10 April 1984, Case 14/83.

${ }^{43}$ Judgment Kolpinghuis, of 8 October 1987, Case 80/86.

${ }^{44}$ Judgment Maria Pupino, of 16 June 2005, Case C-105/03.

${ }^{45}$ Judgment Marleasing, of 13 November 1990, Case C-106/89.

${ }^{46}$ This qualitative leap comes as a result of the principle of loyal cooperation and will be valid, as set out in recital 9 of the Opinion of Advocate General Van Gerven, even if those provisions have been adopted earlier, that is, not to comply with the Directive.

${ }^{47}$ Judgment Marks \& Spencer, of 11 July 2002, Case C-62/00.
} 
European law confers on the individual, determining the obligation to suppress the national standard -, a fortiori, we can conclude that the national court, when faced with a situation like the one depicted in the unifying judgment, "communication of the work to the public" provided for in Article 149 (2) and in Article 155 both from the CRRC must be interpreted under the terms adopted by the CJEU in the various decisions that we mention, which necessarily imply the non-application of the CLUJ (which is not an immediate source of law even at national level).

In particular, and in the wake of the CJEU's decisions enunciated, we advocate that the national court needs to draw on the following criteria:

i) User: the one who intervenes, in full knowledge of the consequences of its behaviour, to give access to its customers of a broadcast containing the protected work, whether these customers are or not within the emission zone, given that they only have access to the transmission by virtue of the deliberate intervention of the owner of the establishment;

ii) Public:

- Unspecified number of potential recipients - the work is perceived in an appropriate manner by a general audience, as opposed to specific individuals belonging to a private group;

- Significant number of people (as opposed to a possible insignificant number) who have access to the same work and how many of them have access to it in succession;

- The work is transmitted to a new public, i.e., additional public or not considered as original public for approval of the communication;

- The work is transmitted to a public not present at the place where the communication originates;

iii) Profit-making nature: the owner is transmitting the works for profit; there is a cause-effect relationship between the diffusion of works and the increase in clientele.

Having met these criteria and the other factors of the objective and subjective type of the crime of misuse, the delivery of an order of prosecution/pronunciation is imposed, since it is not apparent that the conforming interpretation is prejudicial to legal certainty or to the aggravation of responsibility prohibited by the case law of the CJEU and by national law, even though, in very exceptional cases, one can admit the existence of error on unlawfulness.

Having met these criteria and the other factors of the objective and subjective type of the crime of misuse, the delivery of an order of prosecution/pronunciation is imposed, since it is not apparent that the conforming interpretation is prejudicial to legal certainty or to the aggravation of responsibility prohibited by the case law of the $\mathrm{CJEU}^{48}$ and by national law, even though, in very exceptional cases, one can

\footnotetext{
${ }^{48}$ Merely by the way of example in Judgement Kolpinghuis - given that the directive in question in this case had not yet been transposed into Italian law - the CJEU ruled that "that obligation on the national court to refer to the content of the directive when interpreting the relevant rules of its national law is limited by the general principles of law which form part of Community law and in particular the principles of legal certainty and non-retroactivity (...) [wherefore] a directive cannot, of itself and independently of a national law adopted by a Member State for its implementation, have the effect of determining or aggravating the liability in criminal law of persons who act in contravention of the provisions of that directive" (emphasis added).
} 
admit the existence of error on unlawfulness. ${ }^{49}$

Should it not succeed, and the national court decides to blindly follow the CLUJ No. 15/2013 - as happened, for example, in the Seizure Order by the Court of Appeal of Coimbra, dated of 10/14/2015,$-{ }^{50}$ the principle of State liability for breach of EU law comes into play with a view to safeguard the rights of individuals, specifically the right to remuneration for public communication of works, arising from obligations that the European legal order imposes on its Member States.

Let us turn once again to the case law of the CJEU. In Köbler ${ }^{51}$ it was concluded, unequivocally, for the admissibility of the Member State responsibility for the exercise of judicial functions that imply the violation of EU law. In fact, "the principle that Member States are obliged to make good damage caused to individuals by infringements of Community law for which they are responsible is also applicable where the alleged infringement stems from a decision of a court adjudicating at last instance. Indeed, this principle, inherent in the system of the Treaty, applies to any infringement of Community law by a Member State, regardless of the authority of the Member State whose act or omission is responsible for the infringement. '\$2

It also considered that the principle of Member State liability for infringement of EU law - explicitly recognized in Francovic $5^{53}$ - more specifically, for acts or omissions of a national court adjudicating at last instance, "does not affect the authority of res judicata." ${ }^{54}$ And it so happens because "proceedings with a view to render the State liable do not have the same purpose and do not necessarily involve the same parties as the proceedings leading to the decision that has acquired the authority of res judicata. Indeed, the plaintiff in an action for damages against the State will, if successful, obtain the condemnation to the reparation of the damage suffered, without calling into question the authority of res judicata of the judicial authority which caused the damage. 55

As for the criteria for State's liability it is necessary to pay attention to the results of Brasserie du Pêcheur. ${ }^{56}$ Consequently, the Member State must compensate the damage caused to the individual as a result of the infringement of EU law provided that i) the legal standard infringed confers rights on individuals, ii) the breach is sufficiently serious, and iii) there is a causal link between the infringement of the obligation incumbent on the State and the damage suffered by the individual. ${ }^{57}$

\footnotetext{
${ }^{49}$ Article 29 (1) of the Constitution of the Republic states that "no one can be criminally sentenced if not pursuant to a previous law that declares the act or omission as punishable, nor endure security measures the preconditions of which are not established in a previous law." It is also established here the well-known principle of legality in criminal law, also proclaimed in Article 1 (1) of the Criminal Code. Although this is not the place for the necessary deepening of this fundamental principle of the rule of law, we shall say that its primary function is of a safeguarding nature as it seeks to undermine illegitimate and abusive exercises of the State's ius puniendi. Therefore, it continues to be postulated that only prosecution and punishment that simultaneously undergo the requirements of foundation and criteria and the legal limits imposed by the principle in question can be said to be political and criminally legitimate, thus preserving legal certainty. In the present case, the principle of legality was fully complied with. What existed was an interpretation by the Supreme Court of Justice that decided to consider a certain conduct as atypical. This fact per se seemed to us insufficient to consider the ab initio infringement of the principle of legal certainty with the delivery of a prosecution order/indictment.

${ }^{50}$ Case No 35/12.0PFVIS.C1.

${ }^{51}$ Judgment Köbler, of 30 September 2003, Case C-224/01.

${ }^{52}$ Cf. recitals n. ${ }^{\circ}$ s 1 and 2.

${ }^{53}$ Judgement Francovich, of 19 November 1991, Joined Cases C-6/90 and C-9/90.

${ }^{54}$ Cf. recital n. ${ }^{\circ} 39$.

${ }^{55}$ Cf. recital n. ${ }^{\circ} 39$.

${ }^{56}$ Judgment Brasserie du Pêcheur, of 5 March 1996, Joined Cases C-46/93 and C-48/93.

${ }^{57}$ Criteria as set out by Alessandra Silveira, in op. cit., p. 186, which also notes that the CJEU admits
} 
It should be noted that a clear infringement of EU law by the national court arises both in cases of non-preliminary ruling - when required $-{ }^{58}{ }^{59}$ or when the decision is made manifestly infringing the case law of the Court of Justice on the matter.

In turn, and as argued by the Attorney General P. Léger in recital 149 of his conclusions - still within the framework of the Köbler judgment - "proof of the causal link requires that the individual be in a position to establish that the failure to make a reference necessarily caused bim actual and certain, not hypothetical, damage which would not have occurred if the supreme court had decided to refer a question for a preliminary ruling."

Note that it is also evident from the case law set by the CJEU that it is unlawful to limit the State's liability to cases of wilful misconduct or gross negligence of the judge. ${ }^{60}$

Take for example, the judgment of the Court of Appeal of Coimbra, dated of 10.14.2015, which emerged in the result of the writ of nolle prosequi by order of a party to the main proceedings, which confirmed the foundations that have been in the genesis of the decision by the Prosecutor's Office that no further investigations would ensue. ${ }^{61}$

The defendant was indicted for committing a crime of misuse for promoting, in his commercial establishment, "the public execution of intellectual works protected by copyright, using for such a sound equipment on the three sound speakers through which the sound was propagated."'62

For this purpose, the party to the main proceedings claimed that the contested decision made an incorrect interpretation of the concept of communication of work to the public under EU law, and in particular Directive 2001/29/EC.

It also suggested that the Court refer the following questions to the CJEU:

i) The concept of communication of work to the public provided for in Article 3 (1) of Directive 2001/29/EC must be interpreted as covering the transmission of broadcast works, in commercial establishments such as bars, to cafes, restaurants or other with similar characteristics, through reception television sets and disclosure which is amplified through speakers and/or amplifiers, setting to that extent, a new use of copyright

\footnotetext{
that "the requirement that the norm confers rights on individuals does not necessarily imply that the standard be provided with direct effect - much less so of direct applicability."

${ }^{58}$ I.e., when we are before the Court of the national legal system from which there is no appeal.

${ }^{59} \mathrm{It}$ is also urgent to pay attention to Judgement Cilfit, of 6 October 1982, Case 283/81, where the CJEU adopted the following understanding: "the national court required to refer the question for preliminary ruling is exempted from this responsibility if faced with: 1) a provision with a meaning so clear and obvious that it leaves no room for reasonable doubt concerning the solution of the legal matter and the correct application of European Union law, or before 2) a firm statement or consolidated case law of the CJEU," i.e., if the point of law at issue has already been settled by the CJEU, the binding precedent takes effect even if one is not facing a factually identical situation (see, in this sense, Alessandra Silveira, op. cit., p.192). It is certain, moreover, that if the judge wishes to evade the order of obligation, taking advantage of the above-mentioned case law, it must substantiate its claim, in particular, demonstrating that the position adopted is the result of case law of the CJEU or there is no reasonable doubt in the case that imposes the reference for a preliminary ruling, otherwise incurring in liability.

${ }^{60}$ Judgment Traghetti del Mediterraneo, of 13 June 2006, Case C-173/03.

${ }^{61}$ Contrary to what happened with the position taken by the same Court in the preliminary ruling that gave rise to Case C-151/15 mentioned above.

${ }^{62}$ Cf. the judgment of the Court of Appeal of Coimbra, dated of 10.14.2015.
} 
protected works?, ii) the use of speakers and/or amplifiers, i.e. different technical means different from the reception television set, to expand the sound reception influences the response to the previous question? ${ }^{63}$

Without envisaging the need for carrying out a reference for preliminary ruling - being, incidentally, completely silent on this point - and despite admitting that the position adopted is possibly a minority position throughout the EU, the Court of Appeal of Coimbra essentially built on the case law set by the CLUJ No. 15/2013.

In addition to deciding against the CJEU on this matter, the Court of Appeal of Coimbra, despite being exhorted by the party to the main proceedings, did not request for a preliminary ruling, nor did it give reasons for its decision, stressing that the position adopted resulted from CJEU's case law and stated that it did not appear to be any reasonable doubt in the proceedings that would impose the reference for a preliminary ruling.

As for us, there are no doubts that the rule infringed confers rights on individuals, as already said, namely the right to remuneration for public communication of works.

Finally, there is a causal link between the infringement of the obligation incumbent on the State and the damage suffered by the individual, i.e., the decision contrary to EU law necessarily caused the party to the main proceedings harm, actual and certain - equivalent to the remuneration due - and not hypothetical, and that would not have occurred if the Court had decided in line with the case law of the CJEU.

In addition to the responsibility of the State Judge for breach of EU law, it is worthwhile to acknowledge the possibility, in cases of repeated practice, of the Commission initiating infringement proceedings under Article 258 of the CJEU against the infringing Member State.

In short, if the national court encounters the distribution of the sound made by speakers that amplifies it but, that are not part of the television or radio, it should at the earliest point in time, check whether the criteria that we listed above and that result from the CJEU's case law in judgments C-403/08, C-429/08, both of 04.10.2011, and C-135/10, of 15.03.2012, are satisfied.

If so, the judge should, in the vest of a functionally European court, not apply the CLUJ No. 15/2013, from which derives the right to a new remuneration, pursuant to that stated in Articles 155 and 149 (2) of the CRRC without prejudice to any criminal liabilty for the combined provisions of Articles 195 and 197 of the same law.

If the Portuguese courts persist in welcoming the mentioned CLUJ, even in cases that fulfil all the criteria listed by the CJEU as revealing the concept of communication of work to the public, they should be aware of the possibility, on the one hand, of indictment of the Portuguese State by verification of the requirements relating to State liability (judge) for breach of EU law and, on the other, of triggering infringement proceedings by the European Commission.

${ }^{63}$ Idem. 